\title{
Transformational Leadership Relationship, Headmaster Academic Supervi- sion, and Achievement Motivation with Teacher Performance
}

\author{
Nurwati*, Suhaimi, Sutarto Hadi \\ Master Program of Education Management, Universitas Lambung Mangkurat, Banjarmasin 70123, \\ Indonesia
}

Article history:

Submission July 2020

Revised August 2020

Accepted August 2020

*Corresponding author:

E-mail:

nurwatirohmat@yahoo.com

\begin{abstract}
This research aims to describe and analyze if there any relationships of (1) the direct relationship between headmaster transformational leadership and the teacher performance; the headmaster academic supervision with teacher performance; the headmaster transformational leadership and the teacher achievement motivation; and (2) are there any direct relationship between; the headmaster transformational leadership with teacher performance through the achievement motivation; and the headmaster academic supervision with the teacher performance through achievement motivation. This is an ex post facto study with the linear regression analysis, which is simple and multiple. The population in this research is all civil servant teachers in the north Banjarmasin District, Banjarmasin City. The samples of this research are 163 teachers. The researcher collected the data through questionnaire techniques and observation. The analysis was done by using the correlation test and $\mathrm{F}$ test. The results show that: (1) transformational relationship has a direct relationship to teacher performance; the headmaster supervision with the teacher achievement motivation; and (2) there is an indirect relationship of the headmaster transformational leadership and the teacher performance through achievement motivation; the headmaster academic supervision with the teacher performance through achievement motivation. It is recommended that the parties involved in the world of education do monitoring to the transformational leadership, headmaster academic supervision, and the achievement motivation to increase the teacher performance so that the quality of education can be maximized.
\end{abstract}

Keywords: Transformational leadership, headmaster academic supervision, achievement motivation with teacher performance

\section{Introduction}

The development of knowledge and present technologies requires teachers to increase the role of education. It is hoped that students can face the challenge of a quick change era. That is why; the teacher performance is so important. The teacher must be an agent of change, too (Kass \& Miller, 2011). Teacher performance, in this case, is a duty that must be done by a teacher. It is not only to teach but also more on the implementation of the character or morals of the students to face all problems that they may have. That is why; teachers must always increase their performance by reading the book or joining some seminars that will have a good impact on the students (Ülger et al., 2014). Good and maximum performance is expected to enhance the student learning achievement. Maximum performance is certainly preceded by the competency of the teacher is also improved. The quality of teacher performance is stated in The Indonesian Minister of Education Regulation No. 16 of 2007 about Academic Qualification Standards and Teacher Competencies. Competency standards are fully developed into some major competencies that must be possessed by a teacher, namely: (1) Pedagogic competence that is a 
teacher must be able to understand students, to plan and implement learning, to assess learning outcomes, and to develop all the potential possessed by students, (2) Personality competence that is a teacher has mature personal abilities, has a noble character, wise, has the authority and can be a good example for students, (3) Social competence that is a teacher can communicate and interact interactively effective both in the school environment and outside the school, and (4) professional competence that is a teacher can develop themselves as a professional teacher such as mastering learning material, planning and implementing learning and can evaluate learning well. The fourth competency is integrated into teacher performance (Rusman, 2013).

The role of a school headmaster in addition to being managerial, as well as a leader, is very necessary for demonstrating existence as his role to improve the quality of education in his school. A school headmaster is expected to create a community that encourages collaboration to enhance education quality (Aydin \& Hakan, 2015). A school headmaster must manage and control available resources to improve the quality of education effectively and efficiently. Optimization of available resources in schools is an alternative form of an independent and competitive school compared to other schools. The school headmaster is also expected to be able to evaluate teachers (Lavigne \& Olson, 2019).

The ability of the headmaster as a manager in a strategic position in enhancing education quality is crucial because the progress of the school depends on his leadership. So that all the potential in schools can function optimally, it is necessary to adopt a transformational leadership style.

Transformational leadership is a leadership style that prioritizes the development of all the elements that exist within the school to work based on a noble ethical system. All elements in the school (teachers, students, employees, parents, community, and all related elements) are willing without coercion, increasing participation in achieving the school's desired goals (Mukhtar \& Iskandar, 2013). Much research has been done in terms of transformational leadership in schools (Hunt, 1999; Liu et al., 2019; Mitchell, 2019; Donna et al., 2018). This research in transformational leadership can be seen in how school headmasters can make changes to the organizations they lead (Marks \& Printy, 2009).

The quality of education can be improved if teacher learning is carried out effectively and efficiently. To ensure the effectiveness and quality of learning, a supervisor (headmaster) needs to assist the teacher in planning, implementing, evaluating, and following up on learning so that it is more optimal and gets the expected results to improve the performance of the teacher concerned. So, academic supervision is needed by the headmaster.

According to Mukhtar and Iskandar (2013), Learning supervision is supervision to improve the quality of learning and aims to foster teachers to carry out their tasks professionally. Glickman (2007) said that learning supervision is a sequence of activities to help the teachers in improving their competence to make sure that the students achieve the learning objectives. This can be seen from the ways that the teacher does in developing the ability that he has in managing the teaching and learning implementation to achieve the learning objectives to the fullest.

The process of supervision by the headmaster focuses on aspects of teacher performance in the learning process according to the efforts of educational services in improving the quality of the learning process. Academic supervision will provide an overview of the quality of teacher performance in carrying out their duties in managing learning in the classroom (Suharsaputra, 2018).

This weak supervision will also have an impact on weak teacher evaluation and the lack of improvement in teacher pedagogical competence (Wakamatsu, 2016). This supervision and transformational leadership have a strong impact on a school's outcome. (Witziers, Bosker, \& Kruger, 2003; Marks \& Printy, 2009; Hallinger, 2005; Robinson et al., 2008; Leithwood \& Sun, 2012). So these two things are important for improving the quality of schools. But in the implementation of this supervision, the head of the school often has 
problems because of the many responsibilities and performance and lack of time management to do the supervision task to the teacher (Donaldson, et al., 2014; Derrington \& Campbell, 2018; Ayub, 2010; Komarraju et al., 2009). The improvement of teacher resources must start from the existence of internal and external encouragement in the form of strong achievement motivation to increase their potential in developing their competencies to better benefit their students. In general, these two motivations are an important basis for teachers to pursue their careers in teaching (Brookhart \& Freeman, 1992; Kyriacou \& Coulthard, 2000; Karavas, 2010). In motivation theory, someone who has a strong inner motivation will enjoy completing tasks with pleasure, play a role in activities to increase experience to find something new in him (Deci \& Ryan, 2000).

Achievement motivation is about a person's ability to discipline himself and be committed to achievement (Elliot \& Thrash, 2001; Elliot \& Murayama, 2008). It is supported by empirical data, which shows that there is a significant relationship between intrinsic factors in the development of achievement (Tanaka \& Yamauchi, 2001; Lee, Sheldon, \& Turban, 2003; Nien \& Duda, 2008; Chen et al., 2019).

In addition to internal factors, nurturing factors that originate from outside oneself will also affect one's performance. These factors include work safety and safety, working conditions, wage systems, supervision, and interpersonal relationships between colleagues. To achieve maximum results, it takes an element of cooperation to achieve maximum results. Therefore, each individual must be able to naturally integrate external factors to improve performance (Deci \& Ryan, 2000).

The improvement of educational resources, especially teachers' performance, is needed to achieve educational success. The teachers' achievement motivation to improve their competencies to become professional teachers will improve their schools' quality of education. A highly motivated teacher, that always works effectively and efficiently, will produce strong human resources, namely graduates who are efficient and effective by the established educational goals. Teacher performance appraisals are given to differentiate among other teachers
(Kraft \& Gilmour, 2017; Suhaimi, 2019). They state that there is a relationship between teacher achievement motivation, the headmaster's transformational leadership, and the teacher performance directly.

The result of this research can be used by all parties involved in the world of education to design programs that aim at increasing achievement motivation to improve teacher performance both by improving the transformational leadership and academic activities of school headmasters.

\section{Material and Methods Method}

This research is a quantitative study using regression techniques. This simple and multiple regression analysis techniques (path analysis) aim to prove whether or not there is a functional relationship between an independent variable and its dependent variable.

This study involves four variables, namely transformational leadership (X1), headmasters' academic supervision (X2) as independent variables, achievement motivation (Z) as the intervening variables (intermediate variables), and teacher performance (Y) as the dependent variable.

\section{Population}

This research was conducted at 41 elementary schools in the North Banjarmasin District, with 273 teachers who have the characteristics of the potential of students, teachers, and headmasters almost equally.

In this study, population characteristics are all elementary school teachers in the North Banjarmasin sub-district who have the status of civil servants and have teaching experience of more than five years serving as teachers assuming the teacher has had enough experience and maturity of teaching.

\section{Sample}

This research uses the Taro Yamane formula for taking the sample (Riduwan \& Akdon, 2007). Those are as follows:

$$
\mathrm{n}=\frac{\mathrm{N}}{\mathbf{N} \cdot \mathbf{d}^{2}+\mathbf{1}}
$$


Information:

n: number of samples

$\mathrm{N}$ : Number of the population

D: Prescribed precision

According to the calculation results from the formula obtained, the number of precision samples is $0.05 \%$. Then the minimum number of samples needed in the measurement of transformational leadership, academic supervision of school headmasters, and achievement motivation and teacher performance in this study is as much:

\section{$\mathbf{n}=\frac{273}{273.0 .05^{2}+1}$ \\ $=162,5$ is rounded to 163 proportional random sampling. \\ Results and Discussion \\ Characteristic of respondent}

The sampling taken technique used is

Respondent characteristics from the number of 163 teachers were $27.61 \%$ consisting of men and $72.39 \%$ women. So, show more female respondents than men.

\section{Research Trials}

The instrument used was tested through:

a. The Validity Test: The collected data were analyzed with SPS 20 and excel program tools by measuring valid data with the product-moment formula.

b. Reliability Test: The reliability test was carried out with the SPSS 20 program aid with the Cronbach Alpha method greater than 0.6 .

\section{Testing requirements analysis}

a. Normality Test: The normality test is carried out by the Kolmogorov Smirnov test using the IBM SPSS Statistics 20 statistical analysis program. The results of the normality test for the four variables above show a significance value of $0.378 \geq 0.05$. The data is declared as a normal distribution.

b. Linearity Test

The results of linearity aiming X1 against $\mathrm{Y}$ value of Sig deviation from
Linearity $=0.388, \mathrm{X} 2$ against $\mathrm{Y}=0.693$, $\mathrm{Z}$ against $\mathrm{Y}=0.071$. Then it can be concluded the results of the three variable tests on the Y variable indicate that the Sig Deviation from Linearity value> 0.05 so that the three variables have a linear relationship.

c. Homogeneity Test: The homogeneity test is done by using the Homogeneity of Variance Test using the statistical analysis program IBM SPSS Statistics 20 . From the test, it was found that the Sig X1 value of 0,000 ; $\mathrm{X} 2$ is 0,000 , and $\mathrm{Z}$ is 0,000 , so the three variables are sig $<0.05$ so that the data are homogeneous.

d. Multicollinearity: From the table above, it can be seen that the VIF value of X1 is 3,433; X2 values 4.026 and Z 1.397 mean that the VIF value of the three variables is less than ten, so it can be concluded that the variable data does not occur multicollinearity.

\section{Hypothesis test}

a. Simple Regression Test

The direct relationship between transformational leadership variables, the headmaster's academic supervision, motivation, and teacher performance.

b. Multiple Linear Regression

This analysis is used to determine the indirect relationship between the implementation of transformational leadership by the school headmaster and teacher performance through achievement motivation and school headmasters' academic supervision with teacher performance through achievement motivation and the magnitude of influence between variables.

From Table 1, it can be seen that the relationship between the five variables has a Sig $\leq$ 0.005 value. It can be concluded that there is a significant direct relationship of transformational leadership (X1) and teacher performance (Y); headmaster's academic supervision (X2) with teacher performance (Y), achievement motivation (Z) with teacher performance 
$(\mathrm{Y})$, transformational leadership (Y) X1) with achievement motivation (Z), and school headmaster's academic supervision X2) with achievement motivation (Z). It means that the hypothesis that states there is a significant relationship between variables is accepted.

Table 1. Simple regression test result

\begin{tabular}{llrrrrr}
\hline Model & & $\begin{array}{c}\text { Sum of } \\
\text { Squares }\end{array}$ & Df & Mean Square & F & Sig \\
\hline 1 X1-Z-Y & Regresion & 10141.534 & 2 & 5070.767 & 115.083 & $.000^{\mathrm{b}}$ \\
& Residual & 7049.877 & 160 & 44.062 & & \\
& Total & 17191.411 & 162 & & & \\
& Regresion & 10781.560 & 2 & 5390.780 & 134.562 & $.000^{\mathrm{b}}$ \\
& Residual & 6409.851 & 160 & 40.062 & & \\
& Total & 17191.411 & 162 & & & \\
\end{tabular}

Table 2. Multiple regression test

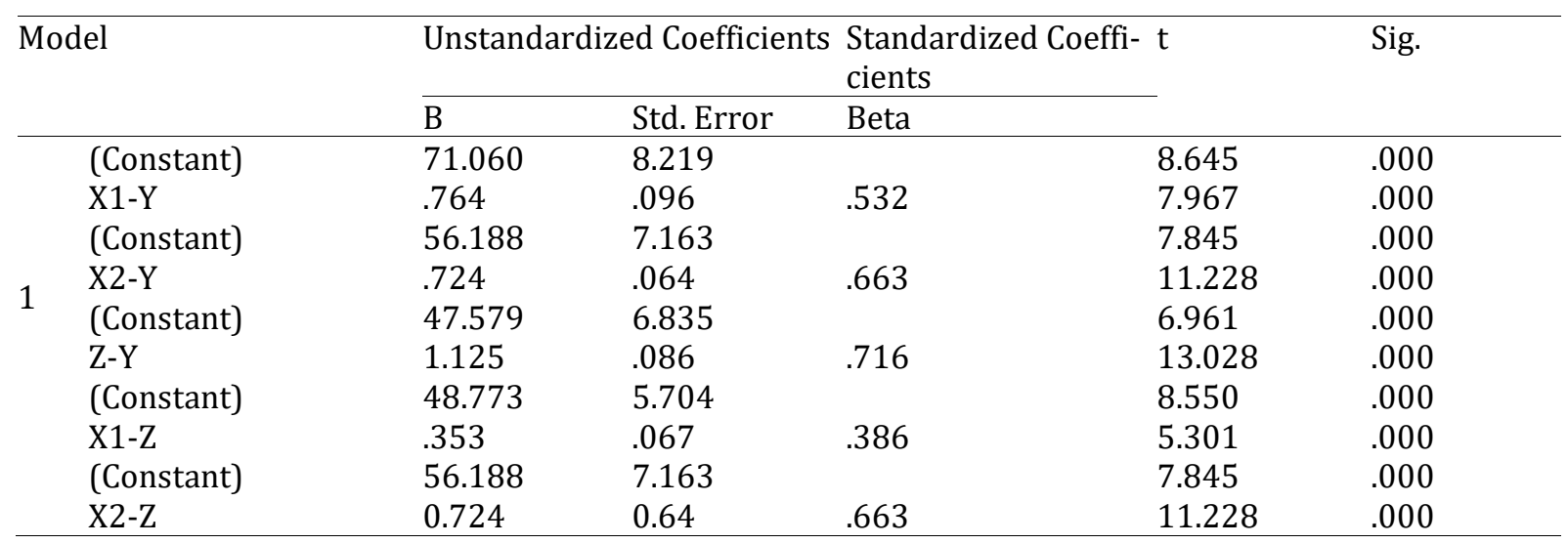

Table 2 shows that the Sig $\leq 0.005$ value. It can be concluded that there is a significant indirect relationship between transformational leadership (X1) and teacher performance (Y) through achievement motivation (Z). There is also an indirect relationship between school supervisors' academic supervision (X2) and teacher performance (Y) through (Z). The influence of the strongest relationship is the indirect relationship of academic supervision (X2) on teacher performance $(\mathrm{Y})$ through achievement motivation (Z) of $62.7 \%$. Meanwhile, the weakest is the effect of transformational leadership relationships (X1) on achievement motivation (Z) by $14.9 \%$. So, it confirms the hypothesis that there is an indirect relationship of transformational leadership, academic supervision of the headmaster, and the performance of teachers through achievement motivation.

Table 3. R Square Test

\begin{tabular}{ccccc}
\hline Model & $\mathrm{R}$ & R Square & $\begin{array}{c}\text { Adjusted R } \\
\text { Square }\end{array}$ & Std. An error of the Estimate \\
\hline $1 \mathrm{X} 1-\mathrm{Y}$ & $.532^{\mathrm{a}}$ & .283 & .278 & 8.75123 \\
$\mathrm{X} 2-\mathrm{Y}$ & $.663^{\mathrm{a}}$ & .439 & .436 & 7.738771 \\
$\mathrm{Z}-\mathrm{Y}$ & $.716^{\mathrm{a}}$ & .513 & .510 & 7.20988 \\
$\mathrm{X} 1-\mathrm{Z}$ & $.386^{\mathrm{a}}$ & .149 & .143 & 6.07354 \\
$\mathrm{X} 2-\mathrm{Z}$ & $.663^{\mathrm{a}}$ & .439 & .436 & 7.73871 \\
$\mathrm{X} 1-\mathrm{Z}-\mathrm{Y}$ & $.768^{\mathrm{a}}$ & .590 & .585 & 6.63790 \\
$\mathrm{X} 2-\mathrm{Z}-\mathrm{Y}$ & $.792^{\mathrm{a}}$ & .627 & .622 & 6.32942 \\
\hline
\end{tabular}


Based on the description above, it is obtained that the magnitude of the direct effect of transformational leadership on teacher performance is $28.3 \%$. From this data, it can be seen the role of transformational leadership's contribution to the performance of teachers in elementary schools in Banjarmasin. Although the impact of transformational leadership is not as big as other factors, it can be concluded that when school headmasters make efforts to change efforts, headmasters need to increase their ability in transformational leadership competencies to improve school outcomes.

Recent research also found significant results in different contexts, namely research conducted by Sangok, Shinhee, Ji Hoon, and Sanghoon (2020) They researched the effects of transformational leadership in two countries, namely the United States and South Korea. The same result obtained in this study is that transformational leadership has an influence, which makes the culture for school organizations support each other in organizing in schools-thus affecting the creation in knowledge. Thus, this study recommends that school leaders focus on developing transformational leadership skills through training development because this is an asset for the organization. This will create habits or culture for learning and have creative thinking to find renewal. Because of the importance of the impact of transformational leadership, another study conducted in Indonesia by Wiyono (2018) recommends for transformational improvement can do a self-evaluation.

The magnitude of the direct effect of academic supervision on headmasters with teacher performance is $43.9 \%$. This data shows that academic supervision has a significant impact on teacher performance. These results are linear with research conducted by Yousaf, Usman, and Islam (2018). This study uses 300 school headmasters and 600 teachers in Pakistan as data. They also use the questionnaire method to get data. The data was then analyzed using t-tests, correlations, and regression analyzes. It is in line with the research results by Poernamawijaya, Sulaiman, Suriansyah, and Dalle (2018). Thus, it is necessary to focus on increasing supervision and developing teacher professionalism in the form of training. In its implementation, the teacher is still not good at creating breakthroughs for formal education (Eraut, 2004; Poulson \& Avramidis, 2003). It is especially useful in utilizing the latest technology in teaching and learning (Ariani et al., 2014).

The amount of direct influence of achievement motivation with teacher performance was $38.6 \%$. This data shows that intrinsic motivation in the form of achievement motivation is vital in enhancing teacher performance. This result is supported by the results of research from $\mathrm{Oz}$ (2016), which states that when a teacher can compile motivational presenting, it will improve teacher performance. This study uses a quantitative method with a survey to obtain data. Oz (2016) says that to improve performance requires the clarity of achievement motivation. In this case, the headmaster is expected to provide clear direction and evaluation to determine what achievements must be achieved in the teachers' performance.

The magnitude of the effect of transformational leadership on achievement motivation is $38.6 \%$. This study also shows that the role of headmasters, especially transformational leadership, in teacher achievement motivation. Suarsih (2017) conduct the same study as the research method; descriptive analysis, quantitative approach, analytical techniques with product-moment correlation, determination, and regression using SPSS Software from 20 existing responses with elementary school teacher respondents.

The results obtained reinforce this research that there is a significant influence between transformational leadership on achievement motivation. The states that individual sensitivity is needed by the school's leadership because each organization has its challenges and problems ( Suarsih, 2017). Besides, another recommendation for improving learning by organizational characteristics and the area where the teacher works. It is what causes the development of progress can be measured. The magnitude of the effect of academic supervision on headmasters with achievement motivation was $66.3 \%$. This data shows that the higher the headmaster carries out supervision, 
the greater the influence on achievement motivation. The same thing was stated by research conducted by Lavigne \& Olson (2019).

This study used respondents from 568 headmasters in the United States. This study states that formal supervision, such as observation in class and giving feedback, significantly affects the achievement motivation. The results of this study need to be emphasized because school headmasters should be given a certain period to find a supervision model that follows the local characteristics of the organization or school. Secondly, in supervising school headmasters can use the results of data, grades, and student achievement separately to improve achievement motivation. Among them is by increasing learning instructions from a teacher. Finally, the supervision assessment emphasizes the local elements where the school is located. It is useful for measuring the ability and motivation of teacher achievement. The supervision model developed can be adapted based on the school context.

\section{Conclusion}

This research can be concluded that there is a direct and significant relationship between the school headmaster transformational leadership and the teacher performance of 28.3\%; the academic supervision of school headmasters and the teacher performance of $43.9 \%$; the achievement motivation and the teacher performance of $38.6 \%$; the transformational leadership to the achievement motivation by $38.6 \%$; and the academic supervision of school headmasters with the achievement motivation of $66.3 \%$, and there is a significant indirect effect between the transformational leadership and the teacher performance through the achievement motivation of $76.8 \%$; and the academic supervision of school headmasters and the teacher performance through achievement motivation of $62.7 \%$.

\section{Acknowledgment}

The authors say thanks to Master Program of Education Management, Universitas Lambung Mangkurat, Banjarmasin 70123, Indonesia for supporting this research.

\section{References}

Ariani, D. N., Saad, N. S., Yusuf, Q., \& Dalle, J. (2014). The Technological Pedagogical Content Knowledge (TPACK) among Mathematics Teachers In Primary Schools. International Conference on Teacher Education, (pp. 1-9). Brunei Darussalam.

Aydin, B., \& Hakan, K. B. (2015). School Headmasters' Roles in Establishing Collaborative Professional Learning Communities at Schools. Procedia - Social and Behavioral Sciences, 197, 1340-1347. doi:https://doi.org/10.1016/j.sbspro.2015.07.387.

Ayub, N. (2010). Effect of intrinsic and extrinsic motivation on academic performance. Pakistan Business Review, 8, 363372.

Brookhart, S. M., \& Freeman, D. J. (1992). Characteristics of entering teacher candidates. Review of Educational Research, 62, 37-60. doi:10.3102/00346543062001037

Chen, C., Elliot, A. J., \& Sheldon, K. M. (2019). Psychological need support as a predictor of intrinsic and external motivation: the mediational role of achievement goals. Educational Psychology, 39(8), 1090-1113. doi:10.1080/01443410.2019.1618442

Deci, E. L., \& Ryan. (2000). The "what" and "why" of goal pursuits: Human needs and the self-determination of behavior. Psychological Inquiry, 11(4), 227-268. doi:10.1207/S15327965PLI1104_01

Deci, E., Vallerand, R., Pelletier, L., \& Ryan, R. (1991). Motivation and education: The self-determination perspective. The Educational Psychologist, 26, 325-346.

Derrington, M. L., \& Campbell, J. W. (2018). Teacher evaluation policy tools: Headmasters' selective use in instructional leadership. Leadership and Policy in Schools, 17(4), 568590.

doi:https://doi.org/10.1080/15700763.2017.1326143

Donaldson, M. L., Cobb, C. D., LeChasseur, K., Gabriel, R., Gonzales, R., Woulfin, S., \& Makuch, A. (2014). An evaluation of the pilot implementation of Connecticut's system for educator effectiveness and development. Retrieved from www.connecticutseed.org/wpcontent/.../Neag Final SEED Report 1-1-2014.pdf

Donna M, G., Dollarhide, C. T., Conley, A. H., \& Lowe, C. (2018). The Construction and Validation of the School Counseling Transformational Leadership Inventory. Journal of Counselor Leadership and Advocacy, 5(1), 1-12. doi:10.1080/2326716X.2017.1399246.

Elliot, A. J., \& Murayama, K. (2008). On the measurement of achievement goals: Critique, illustration, and application. Journal of Educational Psychology, 100(3), 613-628. doi:10.1037/00220663.100.3.613

Elliot, A. J., \& Thrash, T. M. (2001). Achievement goals and the hierarchical model of achievement motivation. Educational 


\begin{tabular}{llllll}
\hline $\begin{array}{l}\text { Psychology } \\
\text { doi:10.1023/A:1009057102306 }\end{array}$ & 13(2), & 139-156. & Administration Quarterly, & 48, & $387-423$. \\
\end{tabular}

Eraut, M. (2004). Informal learning in the workplace. Studies in Continuing Education(26), 247-273. doi:10.1080/158037042000225245

Glickman, C. D. (2007). Supervision and instructional leadership. New York: Omegatype Typography, Inc.

Hallinger, P. (2005). Instructional leadership and the school headmaster: A passing fancy that refuses to fade away. Leadership and Policy in Schools, 4(3), 221-239. doi:0.1080/15700760500244793

Hunt, J. G. (1999). Transformational/charismatic leadership's transformation of the field: An historical essay. The Leadership Quarterly, 10(2), 129-144. doi:10.1016/S10489843(99)00015-6.

Karavas, E. (2010). How satisfied are Greek EFL teachers with their work?: Investigating the motivation and job. Porta Linguarum, 14, 59-78.

Kass, E., \& Miller, E. C. (2011). Bedouin special-education teachers as agents of social change. Teaching and Teacher Education, 27(4), 788-796. doi:https://doi.org/10.1016/j.tate.2011.01.004.

Komarraju, M., Karaub, S., \& Schmeck, R. (2009). Role of the Big Five personality traits in predicting college students' academic motivation and achievement. Learning and Individual Differences, 19, 47-52.

Kraft, M. A., \& Gilmour, A. F. (2017). Revisiting the widget effect: Teacher evaluation reforms and the distribution of teacher effectiveness. Educational Researcher, 46(5), 234-249.

Kyriacou, C., \& Coulthard, M. (2000). Undergraduates' views of teaching as a career choice. Journal of Education for Teaching, 26, 117-126. doi:10.1080/02607470050127036

Lavigne, A. L., \& Olson, A. M. (2019). teacher Evaluation Through the Eyes of the Headmaster: How Individual and School Contexts Shape Perceptions of Practice. 1-22. doi:10.1080/15700763.2019.1637899

Lavigne, A. L., \& Olson, A. M. (2019). Teacher Evaluation Through the Eyes of the Headmaster: How Individual and School Contexts Shape Perceptions of Practice. Leadership and Policy in Schools, 1-22. doi:10.1080/15700763.2019.1637899

Lee, F. K., Sheldon, K. M., \& Turban, D. B. (2003). Personality and the goal-striving process: The influence of achievement goal patterns, goal level, and mental focus on performance and enjoyment. Journal of Applied Psychology, 88(2), 256265. doi:10.1037/0021-9010.88.2.256

Leithwood, K., \& Sun, J. (2012). The nature and effects of transformational school leadership: A meta-analytic review of unpublished research. Educational between transformational leadership and collective teacher efficacy in Chinese primary schools. International Journal of Leadership in Education, 1-14. doi:10.1080/13603124.2019.1623922

Marks, H. M., \& Printy, S. M. (2009). Integrated leadership: How headmasters and teachers share. Journal of School Leadership, 19(5), 504-532.

Mitchell, R. M. (2019). Enabling School Structure \& Transformational School Leadership: Promoting Increased Organizational Citizenship and Professional Teacher Behavior. Leadership and Policy in Schools, 18(4), 614-627. doi:10.1080/15700763.2018.1475577

Mukhtar, \& Iskandar. (2013). A new orientation on educational supervision. Jakarta: Gaung Persada Press Group.

Nien, C.-L., \& Duda, J. L. (2008). Antecedents and consequences of approach and avoidance achievement goals: A test of gender invariance. Psychology of Sport and Exercise, 9(3), 352-372. doi:10.1016/j.psychsport.2007.05.002

Oz, H. (2016). Academic Motivation and Academic Achievement among Preservice English Teachers: A Structural Equation Modeling Approach. The Anthropologist, 25(3), 240-248. doi:10.1080/09720073.2016.11892112

Poernamawijaya, L. W., Sulaiman, S., Suriansyah, A., \& Dalle, J. (2018). Contribution on supervision of the supervisor, headmasters motivation, kindergarten teacher performance to improving the kindergarten quality in West Banjarmasin, Indonesia. European Journal of Alternative Education Studies, 3(2), 129-146. doi:10.5281/zenodo.2261031

Poulson, L., \& Avramidis, E. (2003). Pathways and possibilities in professional development: Case studies of effective teachers of literacy. British Educational Research Journal, 29, 543-560. doi:10.1080/01411920301846

Riduwan, \& Akdon. (2007). Formula in statistics. Bandung: Alfabeta.

Robinson, V. M., Lloyd, C. A., \& Rowe, K. J. (2008). The impact of leadership on student outcomes: An analysis of leadership type. Educational Administration Quarterly, 44(5), 635674. doi:10.1177/0013161X08321509

Rusman. (2013). Quality school management series of learning models developing teacher professionalism. Jakarta: PT Raja Grafindo Persada.

Ryan, R. M., \& Deci, E. L. (2000). Intrinsic and extrinsic motivations: Classic definitions and new directions. Contemporary Educational Psychology.. 25(1), 54-67. doi:10.1006/ceps.1999.1020 
Sangok, Y., Shinhee, J., Ji Hoon, S., \& Sanghoon, B. (2020). Transformational leadership and knowledge creation practices in Korean and US schools: knowledge assets as mediators, knowledge. Management Research \& Practice, 1-13. doi: 10.1080/14778238.2020.1767519

Shih, S.-S. (2008). The relation of self-determination and achievement goals to Taiwanese eighth graders' behavioral and emotional engagement in schoolwork. The Elementary School Journal, 108(4), 3-13. doi:10.1086/528974

Suarsih, C. (2017). Headmaster's transformational leadership and teacher achievement motivation towards teacher performance. The education administration journal, XXIV(4), 14-19.

Sugiyono. (2018). Quantitative research methods. Bandung: CV Alfabeta.

Suhaimi. (2019). Relationship of transformational leaders of headmaster, teacher motivation, teacher organization commitments with a performance of primary school teachers in Labuan Amas Selatan, Indonesia. European Journal of Education Studies, 5, 123-141.

Suharsaputra, U. (2018). Teacher supervision and approach based on performance. Jakarta: Refika Aditama.

Tanaka, A., \& Yamauchi, H. (2001). A model for achievement motives, goal orientations, intrinsic, interest, and academic achievement. Psychological Reports, 1, 123-135. doi:10.2466/PR0.88.1.123-135

Ülger, M., Yiğittir, S., \& Ercan, 0. (2014). Secondary School Teachers' Beliefs on Character Education Competency. Procedia - Social and Behavioral Sciences, 131, 442-449. doi:https://doi.org/10.1016/j.sbspro.2014.04.145.

Wakamatsu, K. (2016). Teacher evaluation and headmaster perception: How arts integration may be key to elevating dance. Arts Education Policy Review, 117(4), 203-210. doi:10.1080/10632913.2016.1211924

Witziers, B., Bosker, R. J., \& Kruger, M. L. (2003 ). Educational leadership and student achievement: The elusive search for an association. Educational Administration Quarterly, 39(3), 398-425. doi:10.1177/0013161X03253411

Wiyono, B. B. (2018). The effect of self-evaluation on the headmasters' transformational leadership, teachers' work motivation, teamwork effectiveness, and school improvement. International Journal of Leadership in Education, 21(6), 705-725. doi:10.1080/13603124.2017.1318960

Yousaf, S., Usman, B., \& Islam, T. (2018). Effects of Supervision Practices of Headmasters on Work Performance and Growth of Primary School Teachers. Bulletin of Education and Research, 40, 285-298. Retrieved from https://search.proquest.com/docview/2103037651?acco untid $=149218$ 